\title{
Plant characteristics associated with widespread variation in eelgrass wasting disease
}

\author{
Maya L. Groner ${ }^{1,7, *}$, Colleen A. Burge ${ }^{2}$, Catherine J. S. Kim ${ }^{3}$, Erin Rees ${ }^{1}$, \\ Kathryn L. Van Alstyne ${ }^{4}$, Sylvia Yang ${ }^{4}$, Sandy Wyllie-Echeverria ${ }^{5,6}$, C. Drew Harvell ${ }^{3}$ \\ ${ }^{1}$ Centre for Veterinary and Epidemiological Research, Department of Health Management, Atlantic Veterinary College, \\ University of Prince Edward Island, Charlottetown, PE C1A 4P3, Canada \\ ${ }^{2}$ Institute of Marine and Environmental Technology, University of Maryland Baltimore County, Baltimore, MD 21202, USA \\ ${ }^{3}$ Department of Ecology \& Evolutionary Biology, Cornell University, Ithaca, NY 14850, USA \\ ${ }^{4}$ Shannon Point Marine Center, Western Washington University, Anacortes, WA 98221, USA \\ ${ }^{5}$ Friday Harbor Laboratories, University of Washington, Friday Harbor, WA 98250, USA \\ ${ }^{6}$ Center for Marine and Environmental Studies, University of the Virgin Islands, St. Thomas, VI, USA \\ ${ }^{7}$ Present address: Dept. of Fisheries, Virginia Institute of Marine Science, 1208 Greate Road, Gloucester Point, VA 23062, USA
}

\begin{abstract}
Seagrasses are ecosystem engineers of essential marine habitat. Their populations are rapidly declining worldwide. One potential cause of seagrass population declines is wasting disease, which is caused by opportunistic pathogens in the genus Labyrinthula. While infection with these pathogens is common in seagrasses, theory suggests that disease only occurs when environmental stressors cause immunosuppression of the host. Recent evidence suggests that host factors may also contribute to disease caused by opportunistic pathogens. In order to quantify patterns of disease, identify risk factors, and investigate responses to infection, we surveyed shoot density, shoot length, epiphyte load, production of plant defenses (phenols), and wasting disease prevalence in eelgrass Zostera marina across 11 sites in the central Salish Sea (Washington state, USA), a region where both wasting disease and eelgrass declines have been documented. Wasting disease was diagnosed by the presence of necrotic lesions, and Labyrinthula cells were identified with histology. Disease prevalence among sites varied from 6 to $79 \%$. The probability of a shoot being diseased was higher in longer shoots, in patches of higher shoot density, and in shoots with higher levels of biofouling from epiphytes. Phenolic concentration was higher in diseased leaves. We hypothesize that this results from the induction of phenols during infection. Additional research is needed to evaluate whether phenols are an adaptive defense against Labyrinthula infection. The high site-level variation in disease prevalence emphasizes the potential for wasting disease to be causing some of the observed decline in eelgrass beds.
\end{abstract}

KEY WORDS: Opportunistic pathogens - Seagrass declines - Phenols · Plant defenses . Labyrinthula $\cdot$ Coastal ecosystems $\cdot$ Restoration $\cdot$ Zostera marina

\section{INTRODUCTION}

Recent data suggest that infectious diseases are increasing in both incidence and severity in the ocean (Harvell et al. 2004, Ward \& Lafferty 2004). The effects of marine diseases can be especially pro- nounced when these diseases negatively impact ecosystem engineers such as reef-building corals (Aronson \& Precht 2001), sea urchins (Feehan \& Scheibling 2014), oysters (Mann et al. 2009), abalone (reviewed by Burge et al. 2014), and seagrasses (Cottam 1933, Short et al. 1987). Ecosystem engineers provide habi- 
tat and ecosystem services, and understanding the factors that lead to increased prevalence and severity of disease in these species is critical for conservation of marine biodiversity and ecosystem function in the face of our changing oceans.

Wasting disease is one of many causes of global seagrass declines and threatens the numerous ecosystem functions provided by seagrass (Orth et al. 2006, Sullivan et al. 2013). Caused by intracellular infection of the host mesophyll by opportunistic protists of the genus Labyrinthula, wasting disease affects several species of seagrass (Muehlstein et al. 1988, 1991, Sullivan et al. 2013). Disease outbreaks have the potential to cause rapid, dramatic population declines, which can compromise the ecosystem services provided by these plants. In the early 1930s, an outbreak along the Atlantic coasts of North America and Europe resulted in up to $90 \%$ mortality of eelgrass Zostera marina populations (Cottam 1933, Short et al. 1987). Smaller, more isolated epidemics have been documented in $Z$. marina populations along the Atlantic and Pacific coasts of North America since the 1980s (Short et al. 1987, Groner et al. 2014). However, aside from extreme outbreaks, the impact of chronic infections on seagrass declines is relatively unknown. Loss of seagrass habitats compromises habitat for economically valuable invertebrates, fish, and birds, and affects the ecosystem services provided by these systems, including the stabilization of of coastal sediments, biological filtration of terrestrial-derived nutrients, carbon sequestration, and local buffering of ocean $\mathrm{pH}$ (Barbier et al. 2011, Fourqurean et al. 2012, Plummer et al. 2013).

Targeted monitoring of diseases and their associated risk factors is critical for early detection and mitigation of marine diseases (e.g. Groner et al. 2015). For many opportunistic pathogens, environmental risk factors cause disease by compromising physiological host defenses (Burge et al. 2013). Recent studies have identified salinity, temperature, and turbidity as factors contributing to wasting disease (McKone \& Tanner 2009, Bull et al. 2012, Groner et al. 2014). A potentially overlooked facilitator of disease from opportunistic pathogens is host population structure. Defenses against pathogens often change during development and may be compromised by stressors such as density, reduced light penetration, for example as caused by growth of epiphytes on leaves, or an individual's microbial community (Kazan \& Manners 2009). Indeed, recent studies have shown that leaf age and plant size are important determinants of disease in eelgrass (Groner et al. 2014).
Defenses of eelgrass against Labyrinthula are not well understood; however, phenolic compounds may play a role (Buchsbaum et al. 1990, Vergeer et al. 1995, Vergeer \& Develi 1997, Sneed 2005, TrevathanTackett et al. 2015). Phenolic compounds produced by $Z$. marina have been correlated with resistance to wasting disease (Buchsbaum et al. 1990) and are capable of inhibiting growth of Labyrinthula in vitro (Vergeer et al. 1995). However, it is not known whether phenols produced in vivo are capable of inhibiting infections.

Since the early 1990s, a number of eelgrass beds in the Salish Sea, located in the northeast Pacific Ocean, have experienced periodic mortalities and are declining from unknown causes (Wyllie-Echeverria et al. 2003, 2010, Dowty et al. 2010, Washington State Department of Natural Resources 2015). Hypothesized causes for these declines include wasting disease and sulfide toxicity (Dooley et al. 2013, Groner et al. 2014). Wasting disease has long been observed in this system (Muehlstein et al. 1991, Muehlstein 1992), and pathogenic strains of L. zosterae have been isolated from diseased leaves (Groner et al. 2014).

In this study, our primary objectives were to identify eelgrass beds with high disease prevalence and to quantify risk factors for disease that could occur at the host level. We surveyed 11 sites throughout the San Juan Archipelago and Puget Sound (i.e. the central Salish Sea). We focused on the role of 3 factors in altering disease prevalence: shoot length, shoot density, and biofouling of leaves by epiphytes. We hypothesized that increases in each of these factors would lead to increased disease prevalence. A second objective of our study was to quantify the relationship between phenolic compounds and disease. We hypothesized that, across sites, diseased leaves would have greater phenolic concentration than healthy leaves.

\section{MATERIALS AND METHODS}

\section{Field survey}

We sampled 11 sites in the San Juan Archipelago and Northern Puget Sound regions of the Salish Sea in Washington state, USA, between 19 and 24 July 2013 (Fig. 1). We focused on this region because declines in the distribution and density of Zostera marina were documented at several sites in the early 2000s (Wyllie-Echeverria et al. 2003, 2010, Ferrier \& Berry 2010). Some of these sites show evidence of population decline, while others have remained stable (Fig. 1, Table 1). 


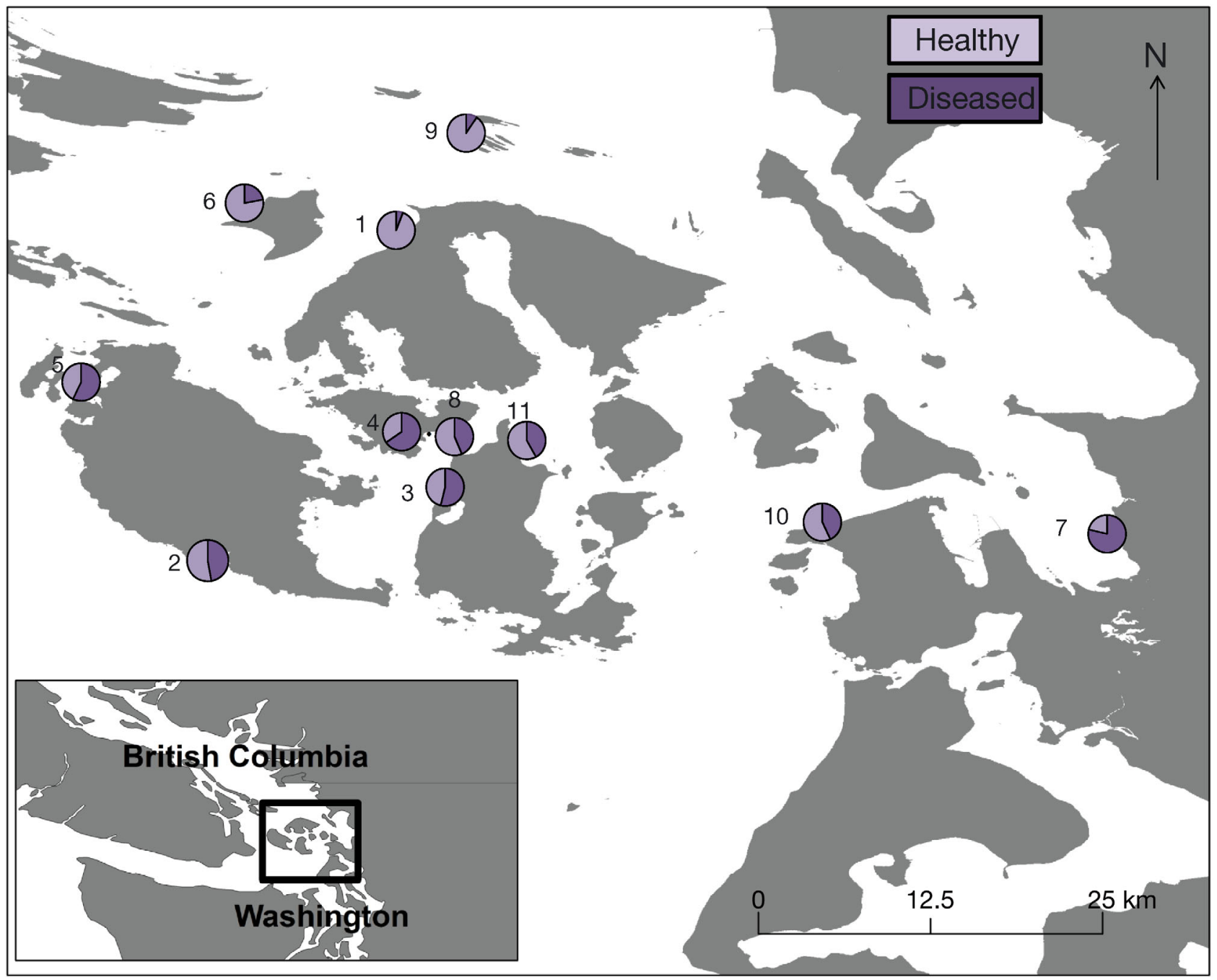

Fig. 1. Prevalence of eelgrass wasting disease (as analyzed on the second longest leaf in surveyed shoots of Zostera marina) among study sites: (1) Beach Haven, (2) False Bay, (3) Fisherman Bay, (4) Indian Cove, (5) Mosquito Bay, (6) North Cove, (7) Padilla Bay, (8) Picnic Cove, (9) Shallow Bay, (10) Ship Harbor, (11) Shoal Bay

At each site, data were collected along 3 transects (each $50 \mathrm{~m}$ long) laid $2 \mathrm{~m}$ apart and parallel to the shore in the intertidal region, with the middle transect at approximately $-1 \mathrm{~m}$ Mean Lower Low Water. Each $50 \mathrm{~m}$ transect was divided into $10 \mathrm{~m}$ sections $(\mathrm{n}=5)$, and in each section, the second oldest leaf was collected from 10 randomly selected shoots. We surveyed the second oldest intact leaf in a shoot to standardize our measurements. We picked this leaf to be conservative, since the older leaves were slightly senescent and much more likely to have lesions, while the youngest leaves may not have been present long enough to present lesions even if the shoot was diseased. In order to determine site-level differences in population density, we also counted the number of shoots in 3 quadrats $\left(0.12 \mathrm{~m}^{2}\right.$ each) per transect (at 0,25 , and $50 \mathrm{~m}$ ). The mean density for each transect was used in the analyses.

Collected leaves were placed in coolers and taken to the Seagrass Lab, Friday Harbor Laboratories, WA, USA, for further measurement. For each leaf, we measured length and width, and described disease status (healthy or diseased) based on visual characteristics. Leaves were diagnosed with wasting disease if they had lesions with irregular, dark, necrotic centers surrounded by a black border (e.g. Burdick et al. 1993, Groner et al. 2014). For 2 of the leaves collected in each $10 \mathrm{~m}$ section, we measured the dry weight of all attached epiphytes. We scraped off all epiphytes from both sides of the leaves onto weigh paper and dried these samples in a drying oven until the mass remained constant (minimum of $24 \mathrm{~h}$ ). We 
Table 1. Survey site locations and known information on population trends and summaries (means \pm SD) of eelgrass Zostera marina shoot density and length, epiphyte biomass, and wasting disease prevalence at each site. ID numbers as in Fig. 1; $(-)$ sites where population status has not been assessed

\begin{tabular}{|c|c|c|c|c|c|c|c|c|}
\hline ID & Site & $\begin{array}{l}\text { Latitude } \\
\qquad\left({ }^{\circ} \mathrm{N}\right)\end{array}$ & $\begin{array}{l}\text { Longitude } \\
\qquad\left({ }^{\circ} \mathrm{W}\right)\end{array}$ & $\begin{array}{l}\text { Population } \\
\text { trend(s) }\end{array}$ & $\begin{array}{l}\text { Shoot } \\
\text { density } \\
\left(\mathrm{m}^{-2}\right)\end{array}$ & $\begin{array}{l}\text { Shoot } \\
\text { length } \\
\text { (cm) }\end{array}$ & $\begin{array}{c}\text { Epiphytes } \\
\text { (mg cm }{ }^{-2} \\
\text { of shoot) }\end{array}$ & $\begin{array}{c}\text { Prevalence } \\
(\%)\end{array}$ \\
\hline 1 & Beach Haven & $48^{\circ} 41.460^{\prime}$ & $122^{\circ} 57.120^{\prime}$ & Stable $^{a}$ & $297 \pm 129$ & $84.6 \pm 22.9$ & $1.17 \pm 1.12$ & $6 \pm 4$ \\
\hline 2 & False Bay & $48^{\circ} 28.975^{\prime}$ & $123^{\circ} 04.451^{\prime}$ & Declining $^{\mathrm{a}, \mathrm{b}}$ & $136 \pm 42$ & $57.4 \pm 15.0$ & $3.37 \pm 1.85$ & $47 \pm 17$ \\
\hline 3 & Fisherman Bay & $48^{\circ} 31.572^{\prime}$ & $122^{\circ} 55.088^{\prime}$ & Stable $^{\mathrm{a}}$ & $213 \pm 29$ & $59.6 \pm 15.8$ & $0.39 \pm 0.46$ & $54 \pm 4$ \\
\hline 4 & Indian Cove & $48^{\circ} 33.773^{\prime}$ & $122^{\circ} 56.078^{\prime}$ & Stable $^{a}$ & $336 \pm 106$ & $81.0 \pm 17.8$ & $0.52 \pm 0.28$ & $65 \pm 12$ \\
\hline 5 & Mosquito Pass & $48^{\circ} 35.346^{\prime}$ & $123^{\circ} 10.208^{\prime}$ & Declining $^{\mathrm{a}}$ & $214 \pm 4$ & $84.9 \pm 19.3$ & $3.70 \pm 2.19$ & $57 \pm 2$ \\
\hline 6 & North Cove & $48^{\circ} 42.287^{\prime}$ & $123^{\circ} 03.221^{\prime}$ & Declining $^{b}$ & $542 \pm 31$ & $63.8 \pm 12.0$ & $0.70 \pm 0.49$ & $22 \pm 8$ \\
\hline 7 & Padilla Bay & $48^{\circ} 29.690^{\prime}$ & $122^{\circ} 29.244^{\prime}$ & - & $358 \pm 13$ & $58.7 \pm 10.7$ & $1.10 \pm 1.49$ & $79 \pm 13$ \\
\hline 8 & Picnic Cove & $48^{\circ} 33.942^{\prime}$ & $122^{\circ} 55.448^{\prime}$ & Declining $^{\mathrm{a}}$, Stable $^{\mathrm{b}}$ & $75 \pm 43$ & $66.9 \pm 13.7$ & $0.61 \pm 0.72$ & $44 \pm 2$ \\
\hline 9 & Shallow Bay & $48^{\circ} 45.613^{\prime}$ & $122^{\circ} 54.892^{\prime}$ & Declining $^{\mathrm{a}}$ & $19 \pm 19$ & $75.4 \pm 17.1$ & $1.46 \pm 1.16$ & $9 \pm 15$ \\
\hline 10 & Ship Harbor & $48^{\circ} 30.307^{\prime}$ & $122^{\circ} 40.202^{\prime}$ & - & $158 \pm 102$ & $73.4 \pm 16.1$ & $4.91 \pm 2.64$ & $43 \pm 2$ \\
\hline 11 & Shoal Bay & $48^{\circ} 33.215^{\prime}$ & $122^{\circ} 52.499^{\prime}$ & - & $164 \pm 4$ & $70.3 \pm 11.9$ & $1.49 \pm 3.38$ & $42 \pm 23$ \\
\hline
\end{tabular}

then divided the dry weight of the epiphytes by the surface area of the leaf they were collected from to calculate the surface area-standardized epiphyte load. In order to understand the relationship between disease and phenolic content in these populations, we quantified phenolic concentration in 3 visually healthy and 3 visually diseased leaves that were collected along each transect. The processing of leaves described above typically occurred within $12 \mathrm{~h}$ of collection. Plants were kept in bags on ice to prevent further development of disease between collection and processing.

\section{Phenolic measurements}

Eelgrass samples frozen at $-80^{\circ} \mathrm{C}$ were transported to the Shannon Point Marine Center in Anacortes, WA, where they were lyophilized and ground to a fine powder with a SPEX mixer/mill. Samples of approximately $10 \mathrm{mg}$ were weighed and extracted in $80 \%$ methanol overnight in darkness at $-80^{\circ} \mathrm{C}$. The extracts were spun down with a centrifuge, and a $50 \mu \mathrm{l}$ aliquot of each extract was diluted with $950 \mu \mathrm{l}$ of ANSI Type I water. Three replicate $100 \mu \mathrm{l}$ aliquots of each diluted sample were dispensed into the cells of a 96-well microplate. Forty $\mu \mathrm{l}$ of $40 \%$ Folin \& Ciocalteu's phenol reagent (Sigma F9252) were then dispensed into each cell of the microplate. The plates were incubated at $50^{\circ} \mathrm{C}$ with shaking for $5 \mathrm{~min}$, then $100 \mu$ of $2 \mathrm{~N}$ sodium carbonate were added to each well. The absorbance at $765 \mathrm{~nm}$ was read after
30 min of incubation. Caffeic acid was initially used as a standard for these assays to generate phenolic measurements that were caffeic acid equivalents, because a native standard was not available at the time the analyses were run. A native standard was produced at a later time and was standardized to caffeic acid (see Fig. S1 in Supplement 1, available at www.int-res.com/articles/suppl/d118p159_supp/). Because of the strong linear relationship $\left(\mathrm{R}^{2}=0.994, \mathrm{p}<\right.$ 0.001 ) between absorbances obtained with the native standard and absorbances obtained with caffeic acid, we then used this regression to convert the concentrations of phenolic compounds obtained using caffeic acid to concentrations of phenolic compounds based on the native standard. Although the native standard was likely to contain some non-phenolic metabolites, it was more representative of the phenolic compounds in $Z$. marina than the caffeic acid standard.

To obtain the native standard, $10 \mathrm{~g}$ of lyophilized, ground Z. marina collected from Ship Harbor in July 2014 were extracted once in 11 of $70 \%$ acetone containing $5.5 \mathrm{mM}$ ascorbic acid, and twice in $1 \mathrm{l}$ of $80 \%$ methanol containing $5.5 \mathrm{mM}$ ascorbic acid. The extracts were combined and the solvents were evaporated under vacuum with a rotary evaporator until only $200 \mathrm{ml}$ of aqueous extract remained. The extract was partitioned 3 times with hexanes to remove nonpolar metabolites. The remaining aqueous extract was mixed with $50 \mathrm{ml}$ of Sephadex LH-20 (Sigma GE17-0090) and placed into a Kontes $4.8 \mathrm{~cm}$ diameter chromatography column. Non-phenolic metabolites were removed by washing with 3 column vol- 
umes of water. The phenolic compounds were then eluted with 3 column volumes of methanol. Water $(100 \mathrm{ml})$ was added to the methanol fraction, and the methanol was evaporated under vacuum. The remaining aqueous extract was partitioned with 1:1 ethyl acetate:hexanes to remove any remaining nonpolar metabolites. Any remaining solvents in the aqueous fraction were then evaporated under vacuum. The fraction was frozen to $-80^{\circ} \mathrm{C}$ and lyophilized to produce brownish-yellow colored flakes.

\section{Histology}

We subsampled leaves collected in Indian Cove and False Bay (Fig. 1) to qualitatively confirm visual disease diagnostics with histological analysis. Six healthy and 12 diseased leaves from Indian Cove and 10 healthy and 10 diseased leaves from False Bay were used for this analysis. Assessments of 'healthy' or 'diseased' were based on visual characteristics as described above. For each diseased leaf, we sampled an area including the leading edge of the lesion and adjacent, visually healthy, tissue. Samples were fixed for $24 \mathrm{~h}$ in $4 \%$ seawater-buffered formalin, and then stored in $70 \%$ ethanol. At Cornell University's Diagnostic Laboratory, leaves were embedded in paraffin, sectioned $(5 \mu \mathrm{m})$, and stained with hematoxylin and eosin (e.g. Groner et al. 2014). Stained sections were randomized and viewed under a bright field Olympus BH-2 microscope with the Olympus DP-20 camera system. Sections were examined blindly (without demarcation of site or disease status) by a single viewer for the presence/absence of Labyrinthula spp. cells or other parasites within the tissues. The number of Labyrinthula spp. cells was counted at $40 \times$ magnification for three $0.5 \mathrm{~mm}$ fields of view on each slide. Labyrinthula spp. cells stained purple in contrast to pink plant tissue and were located intracellularly within the mesophyll (e.g. Renn 1936, Porter 1972, Groner et al. 2014). Active Labyrinthula spp. cells could be identified by their spindle shape $(\sim 15 \mu \mathrm{m}$ length), and resting Labyrinthula spp. cells could be identified by their slightly smaller round shape. In some cases, extracellular mucus was also observed.

\section{Statistical analyses}

We used mixed effects logistic regression to understand the additive effects of shoot density, shootstandardized epiphyte biomass, and shoot length on the disease status of each individual. We ran all pos- sible additive combinations of these predictors in separate models and evaluated their fit using Akaike's information criterion (AIC). We included site as a random intercept in all models.

We used a linear mixed effect model to quantify the effects of shoot length and disease status (e.g. diseased or healthy) on the phenolic concentration ( $\%$ of dry biomass) of leaves. We ran models with each of these predictor variables separately, both together additively, and both together with an interaction. We then used model selection, minimizing AIC values, to select the best fit model. We included site as a random intercept in all models. The model met the assumptions of normality and homoscedasticity.

All analyses were run in R (R Core Team 2014, v. 3.1.2) using the 'Ime4' package (Bates et al. 2014). R-scripts and datasets for these analyses are available in Supplements 2 and 3 at www.int-res.com/ articles/suppl/d118p159_supp/, respectively.

\section{RESULTS}

\section{Field data}

In total, 1645 samples were collected from the 11 sites. All sites were diseased; prevalence among sites varied from $6 \%$ at Beach Haven to $79 \%$ at Padilla Bay (Fig. 1). The geometric mean of disease prevalence across sites was $34 \%$.

The best fitting model included shoot length, shoot density, and epiphyte biomass. The next best fitting model included only shoot length and epiphyte biomass $(\Delta$ AIC from best model $=1.3$ ). No other models were strong candidates $(\triangle \mathrm{AIC}$ from next best model $=$ 6.4). Longer shoots, high shoot density, and high epiphyte biomass on shoots increased the probability of disease (Fig. 2, Table 1). For every $1 \mathrm{~cm}$ of shoot length, the odds of being diseased increased by $1.8 \%$ $(z=-4.61, p<0.00001)$. For every additional shoot in a $100 \mathrm{~cm}^{2}$ area, the odds of being diseased increased by $19.9 \%(z=1.84, p=0.067)$. For every additional $1 \mathrm{mg}$ of epiphytes per $\mathrm{cm}^{2}$ of shoot, odds of disease increased by $21.9 \%(z=2.88, p=0.003)$.

\section{Phenolics}

We processed 175 samples for phenolic concentrations. The best model included disease status (healthy or diseased) as a fixed effect and site as a random intercept ( $\triangle$ AIC from next best model $=7.5$ ). When diseased and healthy shoots were combined, 

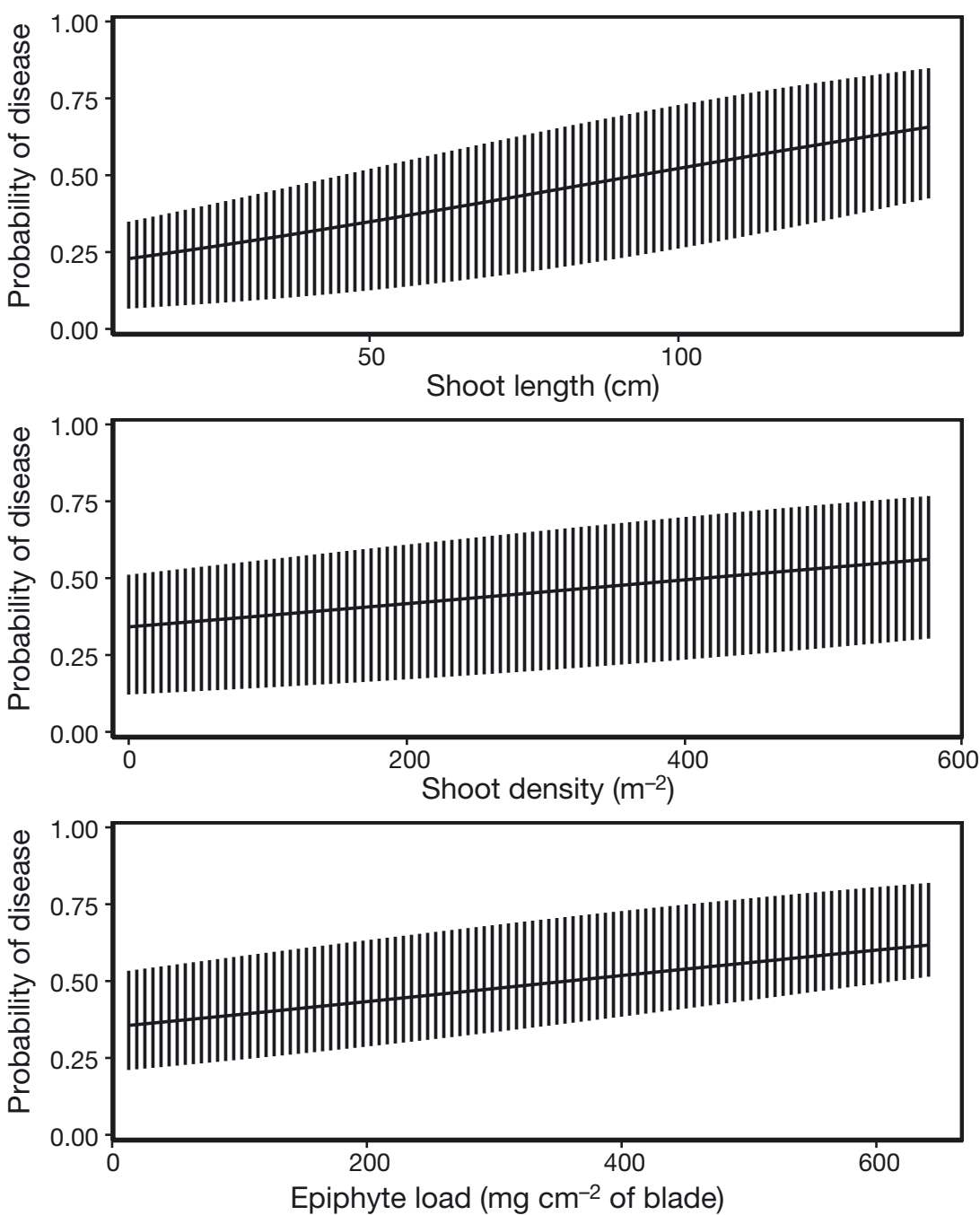

Fig. 2. Effects of eelgrass Zostera marina shoot length, shoot density, and biofouling by epiphytes on the predicted probability that a leaf will have wasting disease. Predicted probabilities were calculated using a logistic regression of shoot length, shoot density, and biofouling by epiphytes on the disease status of a shoot. Vertical lines indicate 25 and $75 \%$ quantiles. For each simulation, 2 variables were held constant, while the variable of interest was allowed to vary. Constants were: shoot length $=70 \mathrm{~mm}$, shoot density $=200$ shoots $\mathrm{m}^{-2}$, epiphyte biomass $=120 \mathrm{mg}$ epiphytes per $1 \mathrm{~mm}$ shoot

the phenolic concentration (mean $\pm \mathrm{SD}$ ) varied across sites from $4.9 \pm 0.5 \%$ of biomass in False Bay to 14.7 $\pm 0.9 \%$ of biomass in Padilla Bay. Across sites, the mean phenolic concentration was $7.5 \pm 0.6 \%$ of biomass in healthy leaves and $8.5 \pm 0.8 \%$ of biomass in diseased leaves. After accounting for random site effects, diseased leaves had an increase in phenolic concentration of 0.76 (in units of $\%$ of biomass, $t=$ $2.33, \mathrm{p}=0.021$; Fig. 3). This corresponds to a $10 \%$ increase in phenolic concentration in diseased plants relative to plants with no lesions. Shoot length did not improve the model fit and was excluded from the final model.

\section{Histology}

Labyrinthula sp. was observed in samples of both healthy and diseased tissue at all sites sampled. Cell counts per field of view were (mean $\pm \mathrm{SD}$ ): healthy: $7.83 \pm 2.16$ (Indian Cove) and $5.1 \pm 2.8$ (False Bay); and diseased: $4.54 \pm 2.30$ (Indian Cove) and $14.7 \pm$ 3.29 (False Bay). Due to the qualitative nature of histological observations, these data were not analyzed statistically. No other potential infectious agents were noted.

\section{DISCUSSION}

Globally, seagrasses are declining at a rate of $7 \% \mathrm{yr}^{-1}$, and identification of factors contributing to these declines is critical for conservation of seagrasses, the habitats that they create, and the ecosystems services that they provide (Waycott et al. 2009). While in a few instances, recent seagrass declines have been associated with disease (Short \& Wyllie-Echeverria 1996), the relation between population decline and disease is more frequently unknown. The prevalence of eelgrass wasting disease varied widely across our study region, from 6 to $79 \%$. This result is similar to findings in the Wadden Sea, where disease prevalence varied from 11 to $80 \%$, (Bockelmann et al. 2013). Our study indicates that eelgrass population structure (i.e. shoot length and density) and fouling are correlated with wasting disease in the Salish Sea. This emphasizes the potential for wasting disease to be contributing to observed population declines. Consistent with previous studies (Buchsbaum et al. 1990, Vergeer et al. 1995, Vergeer \& Develi 1997), we show a potential role for phenols as a defense against disease.

Shoot density and shoot length were positive predictors of disease. Correlations between wasting disease and both shoot density and shoot length have been found in previous field studies. For example, disease was positively correlated with density in European populations of eelgrass (Bull et al. 2012), 


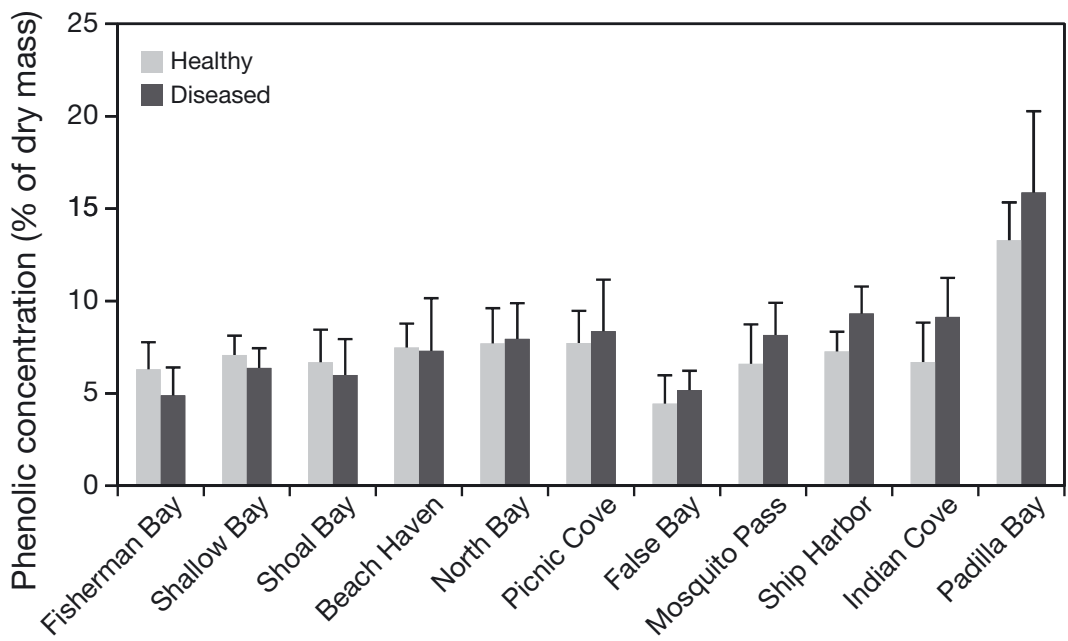

Fig. 3. Phenolic contents (as percent of dry mass equivalents) of healthy (light bars) and diseased (dark bars) eelgrass Zostera marina leaves from 11 sites. The data are means $\pm 1 \mathrm{SD}$. The standard curves used to calibrate the analyses were derived from absorbances obtained from Folin-Ciocalteu analyses using known amounts of extracted phenolic compounds from $Z$. marina collected from Ship Harbor (see Fig. S1 in Supplement 1 at www.int-res.com/articles/ suppl/d118p159_supp/)

and a field survey of 3 sites in the San Juan Archipelago found that longer shoots had higher levels of infection (Groner et al. 2014). Experimental infections also were more successful on older shoots compared to younger shoots on a single ramet (Groner et al. 2014). While trade-offs between shoot length and shoot density are common (Olesen \& Sand-Jensen 1994a, Yang et al. 2013), our model suggests that disease risk may be higher in areas with increased biomass (e.g. beds with short shoots or low density sites with long shoots). It is possible that such populations are at or near their carrying capacity and are experiencing negative density-dependent growth rates as a result of competition or have attained high enough biomass to allow for spread of disease.

The contribution of epiphytes to wasting disease has not been observed previously. One hypothesis for this effect is that the epiphytes cause a reduction in immune defenses by blocking carbon uptake and light, thereby reducing photosynthesis and allocation of resources towards immune defenses (Sand-Jensen 1977). Another hypothesis is that increased nutrients drive the changes in epiphytes, wasting disease, and phenolics. Increased biofouling by epiphytes is frequently indicative of increased nutrient loading (Borum 1985, Williams \& Ruckelshaus 1993), and higher nitrogen levels have been associated with reduced production of phenols and increased wasting disease in experimental treatments (Buchsbaum et al. 1990). Further research is needed to investigate the mechanism behind this relationship.
While disease prevalence was high at several sites, it is unclear what role this may play at the population level. We hypothesize that wasting disease has 2 important effects on eelgrass beds: (1) to lower overall plant fitness, potentially contributing to population declines; and (2) to increase the decay rate of senescing leaves, remineralizing nutrients for availability in the food web (Raghukumar 2002, Raghukumar \& Damare 2011). During warm seasons, leaves are turned over rapidly in eelgrass shoots, and it is likely that the sampled leaves were weeks away from senescing (Olesen \& SandJensen 1994b). Nonetheless, fitness costs may be incurred from wasting disease at high-prevalence sites in the Salish Sea. While wasting disease has previously caused rapid population declines (Atlantic coastlines in the 1930s), more work will be needed to pinpoint how much wasting is contributing to the current population declines in the Salish Sea. The high prevalence of wasting disease and extent of recent eelgrass population declines warrants further investigation into these topics.

Our study supports previous field observations of increased phenolic content in diseased seagrasses (Vergeer \& Develi 1997). This positive association is consistent with some previous laboratory and mesocosm studies (e.g. Buchsbaum et al. 1990, Vergeer et al. 1995, Steele et al. 2005), but not others (McKone \& Tanner 2009). Indeed, the wide variation in the association of disease status on phenolic content found across the 11 sites suggests that, in addition to disease, other factors such as nutrient availability, herbivory, and genetics may be influencing the production of phenols.

Phenolic compounds in seagrasses, including Zostera marina, are a complex mixture of metabolites that include condensed tannins (proanthocyanidin polymers), phenolic acids, flavonoids, and lignins (Van Alstyne \& Padilla in press). In the Salish Sea, the phenolic acids produced by $Z$. marina include ferulic (4-hydroxy-3-methoxycinnamic), vanillic (4hydroxy-3-methoxybenzoic), p-hydroxybenzoic (4hydroxybenzoic), caffeic (3,4-dihydroxycinnamic), gallic $(3,4,5$-trihydroxybenzoic), protocatechuic $(3,4$ dihydroxybenzoic), and gentisic (2,5-dihydroxybenzoic) acid (Quackenbush et al. 1986, Ferrat et al. 2012). No single assay can measure the concentra- 
tions of these structurally diverse compounds. Folin assays, such as the Folin-Ciocalteu assay that was used in this study, provide a measurement of the reducing activity of extracts containing phenolic compounds. This can be used as a proxy for the concentration of the compounds in the plants. The assay measures the ability of hydroxylated aromatic compounds in the extracts to reduce phosphomolybdic and phosphotungstic acid reagents, and reducing ability is thought to be correlated with the biological activity of the compounds (Appel et al. 2001). Because the ability of phenolic compounds to reduce these reagents is dependent on the compounds' structures, changes in 'phenolic contents' of plants, as measured with Folin assays, could result from changes in the amounts of compounds present in the extracts or in their structural types. These assays provide a relatively rapid and inexpensive 'first look' at changes in plant biochemistry that correlate with differences in the plants' environment and disease state, but to understand the specific mechanisms by which plants are responding to pathogens and environmental factors, more detailed analyses of specific compounds (e.g. phenolic acids) or more closely related groups of compounds (e.g. condensed tannins) are needed.

Phenols are associated with disease resistance in many plants (Nicholson \& Hammerschmidt 1992); however, it is unclear whether the association found here is indicative of an adaptive response to infection. Increased production of caffeic acid in response to Labyrinthula spp. infection has been found in $Z$. marina, and caffeic acid can inhibit growth of Labyrinthula spp. in vitro (Buchsbaum et al. 1990, Vergeer et al. 1995, Vergeer \& Develi 1997). In contrast, a potentially non-adaptive pseudo-induction of phenolics in another seagrass species, turtlegrass Thalassia testudinum, is hypothesized to occur when shoots cannot move photosynthates down the leaf past the site of infection (Steele \& Valentine 2012, Trevathan-Tackett et al. 2015). This causes carbohydrates to accumulate above the sites of the Labyrinthula spp. infections, where they are then used to synthesize phenolic compounds (Steele et al. 2005). Finally, Labyrinthula may inhibit production of phenols that are capable of inhibiting growth of in vitro strains (e.g. Sneed 2005). Numerous other factors influence phenolic concentrations in plants. Phenol concentration decreases with blade age (Ravn et al. 1994) and is negatively correlated with environmental factors, including turbidity (Sneed 2005), temperature (Vergeer et al. 1995), ocean acidification (Arnold et al. 2012), low salinity (Sneed 2005), and heavy metal contamination (Ferrat et al. 2012). Mechanistic studies that quantify the locations and types of phenols produced over the course of an infection, and how those phenols affect the growth of Labyrinthula under various environmental conditions, are necessary to characterize the roles of these compounds.

The presence of Labyrinthula spp. cells in both diseased and healthy tissue is consistent with opportunistic pathogens, whereby the presence of pathogens is not necessarily indicative of disease (reviewed by Burge et al. 2013). The wide range of cell densities in the histology samples could reflect a heterogeneous distribution of Labyrinthula spp. in the hosts. Indeed, this is the case with sea fan corals infected with the labyrinthulomycete Aplanochytrium (Burge et al. 2012), and indicates that while histology can be an effective qualitative indicator of pathogen presence and infection of host tissues, it is not an accurate method to measure pathogen load, disease state, or strain. This highlights the importance of quantitative PCR methods for quantifying pathogen load in $L$. zosterae infections. Paired measurements of pathogen load and wasting disease status are necessary to understand whether a specific pathogen load and/or strain is associated with disease status.

We have highlighted the influence of host factors on eelgrass wasting disease prevalence across sites in the central region of the Salish Sea. Many questions remain about what other biotic or abiotic factors contribute to or are necessary for disease expression in Pacific Northwest eelgrass meadows. Other potential risk factors have not been fully evaluated in Pacific eelgrass meadows, including temperature, light, salinity, nutrients, and hydrogen sulfide toxicity (Holmer \& Bondgaard 2001, Dooley et al. 2013, Yang et al. 2013, Kaldy 2014). Moreover, while our survey provides data on wasting disease prevalence across 11 sites, it is a single snapshot in time. Longitudinal studies to track disease progression and eelgrass population status over seasonal and multi-year fluctuations are critical for clarifying the relationship between disease and declining eelgrass meadows. Finally, the role of strain variation in the incidence and severity of wasting disease is not well understood, although preliminary evidence suggests that this variation may be substantial (Groner et al. 2014). Nonetheless, our study highlights the potential for wasting disease to cause eelgrass population declines in the Salish Sea and provides impetus and direction for further research. More broadly, the important role of host demography in the epidemiology of eelgrass wasting disease suggests that demo- 
graphy may be an important area for research in other marine or terrestrial organisms that are infected with pathogenic labyrinthulomycetes.

Acknowledgements. Aissa Yazzie, Holly Moxley-Williams, Diane Ayala, Anna Russell, Nathan Greene, Katherine Boehrer, and Katie Kirk assisted in the field and the laboratory. Thanks also to William Chalmers and 3 anonymous reviewers for insightful comments. This work was funded by the National Science Foundation Ecology and Evolution of Infectious Diseases grant number OCE-1215977 awarded to C.D.H., NSF IOS 1118944 to K.L.V.A., and a Patricia L. Dudley Scholarship awarded to M.L.G. M.L.G. also acknowledges partial support from the Centre for Excellence Research Chair in Aquatic Epidemiology at the Atlantic Veterinary College in Prince Edward Island.

\section{LITERATURE CITED}

Appel HM, Govenor HL, D'Ascenzo M, Siska E, Schultz JC (2001) Limitations of Folin assays of foliar phenolics in ecological studies. J Chem Ecol 27:761-778

> Arnold T, Mealey C, Leahey H, Miller AW, Hall-Spencer JM, Milazzo M, Maers K (2012) Ocean acidification and the loss of phenolic substances in marine plants. PLoS ONE 7:e35107

Aronson RB, Precht WF (2001) White-band disease and the changing face of Caribbean coral reefs. In: Porter JW (ed) The ecology and etiology of newly emerging marine diseases. Springer, Dordrecht, p 25-38

Barbier EB, Hacker SD, Kennedy C, Koch EW, Stier AC, Silliman BR (2011) The value of estuarine and coastal ecosystem services. Ecol Monogr 81:169-193

Bates D, Maechler M, Bolker B, Walker S (2014) lme4: Linear mixed-effects models using Eigen and S4. J Stat Softw 67:1-48

> Bockelmann AC, Tams V, Ploog J, Schubert PR, Reusch TB (2013) Quantitative PCR reveals strong spatial and temporal variation of the wasting disease pathogen, Labyrinthula zosterae in northern European eelgrass (Zostera marina) beds. PLoS ONE 8:e62169

> Borum J (1985) Development of epiphytic communities on eelgrass (Zostera marina) along a nutrient gradient in a Danish estuary. Mar Biol 87:211-218

Buchsbaum RN, Short FT, Cheney DP (1990) Phenolic-nitrogen interactions in eelgrass, Zostera marina L.: possible implications for disease resistance. Aquat Bot 37:291-297

Bull JC, Kenyon EJ, Cook KJ (2012) Wasting disease regulates long-term population dynamics in a threatened seagrass. Oecologia 169:135-142

Burdick DM, Short FT, Wolf J (1993) An index to assess and monitor the progression of wasting disease in eelgrass Zostera marina. Mar Ecol Prog Ser 94:83-90

Burge CA, Douglas N, Conti-Jerpe, I, Weil E, Roberts S, Friedman CS, Harvell CD (2012) Friend or foe: the association of Labyrinthulomycetes with the Caribbean sea fan Gorgonia ventalina. Dis Aquat Org 101:1-12

Burge CA, Kim CJS, Lyles JM, Harvell CD (2013) Special issue oceans and humans health: the ecology of marine opportunists. Microb Ecol 65:869-879

> Burge CA, Eakin CM, Friedman CS, Froelich B and others (2014) Climate change influences on marine infectious diseases: implications for management and society. Annu Rev Mar Sci 6:249-277

Cottam CE (1933) Disappearance of eelgrass along the Atlantic coast. Plant Dis Rep 17:46-53

> Dooley FS, Wyllie-Echeverria S, Ward PD, Roth M (2013) Tolerance and response of Zostera marina seedlings to hydrogen sulfide. Aquat Bot 105:7-10

Dowty P, Berry H, Gaeckle J (2010) Developing indicators and targets for eelgrass in Puget Sound. Nearshore Habitat Program, Washington State Department of Natural Resources, Olympia, WA

> Feehan CJ, Scheibling RE (2014) Effects of sea urchin disease on coastal marine ecosystems. Mar Biol 161: 1467-1485

Ferrat L, Wyllie-Echeverria S, Cates RG, Pergent-Martini C and others (2012) Posidonia oceanica and Zostera marina as potential biomarkers of heavy metal contamination in estuarine and coastal systems. In: Voudouris (ed) Ecological water quality - water treatment and reuse. Intech, Rijeka, p 123-140

Ferrier L, Berry H (2010) Eelgrass (Zostera marina L.) abundance and depth distribution along selected San Juan Archipelago shallow embayments. Nearshore Habitat Program, Washington State Department of Natural Resources, Olympia, WA

Fourqurean JW, Duarte CM, Kennedy H, Marbà N and others (2012) Seagrass ecosystems as a globally significant carbon stock. Nat Geosci 5:505-509

Groner ML, Burge CA, Couch CS, Kim CJS and others (2014) Host demography influences the prevalence and severity of eelgrass wasting disease. Dis Aquat Org 108: 165-175

Groner M, Breyta R, Dobson A, Friedman CS and others (2015) Emergency response for marine diseases. Science 347:1210

Harvell D, Aronson R, Baron N, Connell J and others (2004) The rising tide of ocean diseases: unsolved problems and research priorities. Front Ecol Environ 2:375-382

Holmer M, Bondgaard EJ (2001) Photosynthetic and growth response of eelgrass to low oxygen and high sulfide concentrations during hypoxic events. Aquat Bot 70:29-38

Kaldy JE (2014) Effect of temperature and nutrient manipulations on eelgrass Zostera marina L. from the Pacific Northwest, USA. J Exp Mar Biol Ecol 453:108-115

Kazan K, Manners JM (2009) Linking development to defense: auxin in plant-pathogen interactions. Trends Plant Sci 14:373-382

Mann R, Southworth M, Harding JM, Wesson JA (2009) Population studies of the native eastern oyster, Crassostrea virginica, (Gmelin, 1791) in the James River, Virginia, USA. J Shellfish Res 28:193-220

McKone KL, Tanner CE (2009) Role of salinity in the susceptibility of eelgrass Zostera marina to the wasting disease pathogen Labyrinthula zosterae. Mar Ecol Prog Ser 377: 123-130

> Muehlstein LK (1992) The host-pathogen interaction in the wasting disease of eelgrass, Zostera marina. Can J Bot 70:2081-2088

Muehlstein LK, Porter D, Short FT (1988) Labyrinthula sp., a marine slime mold producing the symptoms of wasting disease in eelgrass, Zostera marina. Mar Biol 99: 465-472

> Muehlstein LK, Porter D, Short FT (1991) Labyrinthula zosterae sp. nov., the causative agent of wasting disease of eelgrass, Zostera marina. Mycologia 83:180-191 
Nicholson RL, Hammerschmidt R (1992) Phenolic compounds and their role in disease resistance. Annu Rev Phytopathol 30:369-389

Olesen B, Sand-Jensen K (1994a) Biomass-density patterns in the temperate seagrass Zostera marina. Mar Ecol Prog Ser 109:283-291

Olesen B, Sand-Jensen K (1994b) Demography of shallow eelgrass (Zostera marina) populations - shoot dynamics and biomass development. J Ecol 82:379-390

Orth RJ, Carruthers TJ, Dennison WC, Duarte CM and others (2006) A global crisis for seagrass ecosystems. Bioscience 56:987-996

Plummer ML, Harvey CJ, Anderson LE, Guerry AD, Ruckelshaus MH (2013) The role of eelgrass in marine community interactions and ecosystem services: results from ecosystem-scale food web models. Ecosystems 16: 237-251

Porter D (1972) Cell division in the marine slime mold, Labyrinthula sp., and the role of the bothrosome in extracellular membrane production. Protoplasma 74:427-448

Quackenbush RC, Bunn D, Lingren W (1986) HPLC determination of phenolic acids in the water-soluble extract of Zostera marina L. (eelgrass). Aquat Bot 24:83-89

R Core Team (2014) R: a language and environment for statistical computing. R Foundation for Statistical Computing, Vienna. www.r-project.org

Raghukumar S (2002) Ecology of the marine protists, the Labyrinthulomycetes (Thraustochytrids and Labyrinthulids). Eur J Protistol 38:127-145

Raghukumar S, Damare VS (2011) Increasing evidence for the important role of Labyrinthulomycetes in marine ecosystems. Bot Mar 54:3-11

Ravn H, Pedersen MF, Borum J, Andary C, Anthoni U, Christophersen C, Nielsen PH (1994) Seasonal variation and distribution of two phenolic compounds, rosmarinic acid and caffeic acid, in leaves and roots-rhizomes of eelgrass (Zostera marina L.). Ophelia 40:51-61

$>$ Renn CE (1936) The wasting disease of Zostera marina. I. A phytological investigation of the diseased plant. Biol Bull (Woods Hole) 70:148-158

Sand-Jensen K (1977) Effect of epiphytes on eelgrass photosynthesis. Aquat Bot 3:55-63

Short FT, Wyllie-Echeverria S (1996) Natural and humaninduced disturbance of seagrasses. Environ Conserv 23: $17-27$

Short FT, Muehlstein LK, Porter D (1987) Eelgrass wasting disease: cause and recurrence of a marine epidemic. Biol Bull (Woods Hole) 173:557-562

Sneed JM (2005) The effects of Labyrinthula sp. infection, salinity, and light on the production of phenolic compounds in Thalassia testudinum. MSc thesis, University of South Florida, Tampa, FL

Steele L, Valentine JF (2012) Idiosyncratic responses of sea-

Editorial responsibility: Rebecca Gast,

Woods Hole, Massachusetts, USA grass phenolic production following sea urchin grazing. Mar Ecol Prog Ser 466:81-92

> Steele L, Caldwell M, Boettcher A, Arnold T (2005) Seagrass-pathogen interactions: 'pseudo-induction' of turtlegrass phenolics near wasting disease lesions. Mar Ecol Prog Ser 303:123-131

Sullivan BK, Sherman TD, Damare VS, Lilje O, Gleason FH (2013) Potential roles of Labyrinthula spp. in global seagrass population declines. Fungal Ecol 6:328-338

> Trevathan-Tackett SM, Lane AL, Bishop N, Ross C (2015) Metabolites derived from the tropical seagrass Thalassia testudinum are bioactive against pathogenic Labyrinthula sp. Aquat Bot 122:1-8

Van Alstyne KL, Padilla DK (in press) The chemical ecology of seagrasses. In: Puglisi-Weening MP, Becerro MA, Paul VJ (eds) Chemical ecology: the ecological impacts of marine natural products. CRC Press, Boca Raton, FL

Vergeer LH, Develi A (1997) Phenolic acids in healthy and infected leaves of Zostera marina and their growth-limiting properties towards Labyrinthula zosterae. Aquat Bot 58:65-72

> Vergeer LHT, Aarts TL, De Groot JD (1995) The 'wasting disease' and the effect of abiotic factors (light intensity, temperature, salinity) and infection with Labyrinthula zosterae on the phenolic content of Zostera marina shoots. Aquat Bot 52:35-44

Ward JR, Lafferty KD (2004) The elusive baseline of marine disease: Are diseases in ocean ecosystems increasing? PLoS Biol 2:e120

Washington State Department of Natural Resources (2015) Puget Sound submerged vegetation monitoring program 2010-2013 report. Available at: www.dnr.wa.gov/Publications/aqr_nrsh_svmp_report_2013.pdf

Waycott M, Duarte CM, Carruthers TJ, Orth RJ and others (2009) Accelerating loss of seagrasses across the globe threatens coastal ecosystems. Proc Natl Acad Sci USA 106:12377-12381

Williams SL, Ruckelshaus MH (1993) Effects of nitrogen availability and herbivory on eelgrass (Zostera marina) and epiphytes. Ecology 74:904-918

Wyllie-Echeverria S, Mumford TE, Gaydos JK, Buffum S (2003) Z. marina declines in San Juan County, WA. Proceedings of the Wescott Bay Taskforce mini-workshop. Available at www.seadocsociety.org/publications (accessed 20 August 2013)

Wyllie-Echeverria S, Talbot SL, Rearick JR (2010) Genetic structure and diversity of Zostera marina (eelgrass) in the San Juan Archipelago, Washington, USA. Estuaries Coasts 33:811-827

- Yang S, Wheat EE, Horwith MJ, Ruesink JL (2013) Relative impacts of natural stressors on life history traits underlying resilience of intertidal eelgrass (Zostera marina L.). Estuaries Coasts 36:1006-1013

Submitted: June 25, 2015; Accepted: December 21, 2015 Proofs received from author(s): February 4, 2016 